\title{
MENINGKATKAN MOTIVASI MAHASISWA DALAM READING COMPREHENSION DENGAN STRATEGI MULTIPLE INTELLIGENCES
}

\author{
A'AM RIFALDI KHUNAIFI \\ Dosen Program Studi Pendidikan Guru Sekolah Dasar Fakultas Keguruan dan Ilmu Pendidikan \\ Universitas Muhammadiyah Palangkaraya \\ Email : aamrifaldi@gmail.com
}

\begin{abstract}
The study discusses about improving students' motivation on reading comprehension by using Multiple Intelligences strategies. The objectives of the study are explaining 1) the problems faced by the Students the first semester at UMP in reading comprehension, 2) the implementation of Multiple Intelligences strategies in motivating reading comprehension for the students the fist semester at UMP, 3) how Multiple Intelligences strategies improve the motivation of the the students the fist semester at UMP in reading comprehension.

In order to achieve the objectives, the researcher held an action research at Muhammadiyah of University. There were 2 cycles in which 2 meetings held for each cycle. The subject of the study is the the students the fist semester at UMP. The numbers of population are 32 students. The instruments used were observation sheet, questionnaire, and CARI.

The result of the study is the problem in motivating students to read. This can be solved by using Multiple Intelligences strategies which combine students' intelligences with fun learning activities by Multiple Intelligence instruction. Based on the questionnaire, all of the students said that the strategies used were interesting. In line with the questionnaire result, the observation sheet also showed excellent result on students' study habits. There was improvement on students' comprehension, it can be seen from the mean of CARI I which was 89.06 point and CARI II which was 95.6 point. In this study, I suggest that the lectures should be able to use the Multiple Intelligences strategies as an alternative in motivating students and creating enjoyable learning experiences.
\end{abstract}

Keywords : multiple intelligences strategies, motivation, reading comprehension.

\section{ABSTRAK}

Penelitian ini ditujukan untuk meningkatkan motivasi belajar mahasiswa pada pemahaman membaca dengan menggunakan strategi Multiple Intelligences. Tujuan dari penelitian ini adalah menjelaskan 1) masalah yang dihadapi oleh mahasiswa semester pertama di Universitas Muhammadiyah Palangkaraya (UMP) dalam pemahaman membaca, 2) pelaksanaan strategi Multiple Intelligences dalam memotivasi pemahaman membaca untuk mahasiswa semester pertama di UMP, 3) bagaimana kecerdasan beberapa strategi meningkatkan motivasi mahasiswa semester pertama di UMP dalam pemahaman membaca.

Untuk mencapai tujuan, peneliti mengadakan penelitian tindakan di UMP. Ada 2 siklus di mana 2 pertemuan diadakan untuk setiap siklus. Subyek penelitian adalah mahasiswa semester satu FIKES di UMP. Jumlah populasi adalah 32 mahasiswa. Instrumen yang digunakan adalah lembar observasi, angket dan CARI.

Hasil dari penelitian ini adalah masalah dalam memotivasi mahasiswa untuk membaca. Hal ini dapat diatasi dengan menggunakan strategi Multiple Intelligences yang menggabungkan kecerdasan mahasiswa dengan kegiatan belajar menyenangkan oleh beberapa instruksi Intelligence. Berdasarkan kuesioner, semua mahasiswa mengatakan bahwa strategi yang digunakan adalah menarik. Sejalan dengan hasil kuesioner, lembar observasi juga menunjukkan hasil yang sangat baik pada kebiasaan belajar siswa. Ada peningkatan pemahaman siswa, dapat dilihat dari rata-rata CARI I 89,06 point dan CARI II 95,6 poin.

Kata kunci : multiple intellegences, motivasi, pemahaman membaca 


\section{PENDAHULUAN}

Bahasa Inggris merupakan bahasa Internasional. Bahasa Inggris di Indonesia diajarkan sebagai bahasa asing (English as a Foreign Languange/EFL) mulai dari Sekolah Dasar sampai Perguruan Tinggi (Huda, 1999, dalam Saukah, 2003). Orang-orang menyadari bahwa pengajaran bahasa Inggris di tingkat ini menjadi sangat penting dan membutuhkan banyak perhatian. Sebagai seorang guru bahasa Inggris, ia dituntut untuk mengeksplorasi teknik yang efektif, metode dan pendekatan.

Bahasa Inggris adalah salah satu bahasa asing yang diajarkan di Indonesia. Hal ini diajarkan dari TK sampai tingkat universitas. Tujuan dari bahasa Inggris mengajar adalah untuk mengembangkan kompetensi komunikatif dan kemampuan mahasiswa. Kemampuan untuk berkomunikasi diwujudkan dalam empat keterampilan berbahasa; yaitu mendengarkan, berbicara, membaca, dan menulis yang digunakan untuk mencapai literasi dan mendukung kompetensi.

Berdasarkan dari pengamatan, peneliti juga melihat bahwa mahasiswa UM Palangkaraya banyak mengalami kesulitan untuk memahami dan mengerti isi teks bacaan. Ketika pemahaman membaca mereka diperiksa oleh dosen bersangkutan, mahasiswa tidak bisa menjawab karena mereka tidak mendapatkan titik apa yang mereka baca, bahkan informasi tertentu dari teks.

Oleh karena itu, jelas bahwa dosen memiliki pekerjaan untuk menemukan cara yang tepat untuk membuat mahasiswa mendapatkan pengetahuan atau memahami teks. Hal ini diperlukan strategi yang digunakan untuk meningkatkan mahasiswa dalam pemahaman membaca sehingga mereka akan lebih menyadari pentingnya membaca, tidak hanya untuk sisi pendidikan, tetapi juga untuk kehidupan seharihari mereka. Mahasiswa akan membaca lebih efektif ketika mereka tahu pentingnya belajar membaca.

Teori Multiple Intelligences adalah salah satu teori di bidang pendidikan saat ini diperkenalkan oleh Gardner. Dalam teori, Gardner di Abdulkader (2009: 4) menolak gagasan kecerdasan tunggal; ada banyak kemampuan manusia yang disebut "Kecerdasan Manusia". Ide Gardner menunjukkan bahwa mahasiswa dapat belajar dengan cara yang berbeda. Oleh karena itu perlu untuk memiliki berbagai pendekatan dan kegiatan.

Rumusan masalah penelitian ini adalah 1) bagaimana strategi Multiple Intelligences dilaksanakan untuk memotivasi mahasiswa Fakultas Kesehatan Semester I Universitas Muhammadiyah Palangkaraya, 2) bagaimana strategi Multiple Intelligences meningkatkan motivasi mahasiswa Fakultas Kesehatan Semester I Universitas Muhammadiyah Palangkaraya dalam Reading Comprehension?

\section{Multiple Intelligences}

Gardner di Armstrong (2005: 19) mendefinisikan kecerdasan sebagai kemampuan untuk memecahkan masalah dan menciptakan produk dengan nilai budaya. Setelah meneliti beberapa jenis kemampuan, kompetensi, dan keterampilan yang digunakan dalam seluruh dunia, Menurut Gardner ada delapan kecerdasan yang perlu diperhatikan:

Linguistik adalah potensi untuk menggunakan bahasa, seperti yang digunakan dalam membaca, menulis, bercerita, menghafal 
tanggal, dan berpikir dalam kata-kata. Dalam kehidupan sehari-hari, menurut Armstrong (2005: 19), kecerdasan ini dapat digunakan untuk berkomunikasi dengan berbicara, mendengarkan, membaca dan menulis. Menurut Kirshenbaum di Jasmine (2007: 18) orang-orang yang memiliki kecerdasan linguistik tinggi dapat tumbuh dan berkembang dengan baik di atmosfer stereotip akademik yang tergantung pada mendengarkan ceramah, mencatat, dan kertas-tes tradisional.

Lwin, et al (2008: 12-15) menambahkan bahwa orang-orang yang memiliki kecerdasan ini mengembangkan kepekaan bahasa dan dengan mudah memanipulasi struktur dan sintaks untuk menyesuaikan diri setiap kebutuhan. Yang penting dari mereka adalah mereka menggunakan bahasa untuk mendapatkan tujuan komunikatif yang mereka inginkan. Orang yang memiliki kecerdasan linguistik yang tinggi akan dengan mudah mempelajari bahasa asing.

Logis-matematis adalah potensi untuk memahami sebab dan akibat, dan untuk memanipulasi angka, jumlah, dan operasi, seperti yang digunakan dalam matematika, penalaran, logika, pemecahan masalah, dan mengenali pola. Lwin et al (2008: 43) menyatakan bahwa konsep logis menjelaskan bagaimana sebuah argumentasi yang terstruktur, bukti, dan persyaratan yang dinyatakan dan kesimpulan yang dibuat. Selain itu, Mirzazadeh (2012: 67) menambahkan bahwa logika-matematika merupakan keterampilan untuk menggunakan nomor efektif dan alasan baik.

Spasial adalah potensi yang mewakili dunia spasial internal dalam pikiran seseorang seperti yang digunakan dalam membaca peta dan grafik, gambar, memecahkan labirin dan teka-teki, membayangkan dan memvisualisasikan. Berdasarkan Armstrong (2005: 20) kecerdasan ini melibatkan kemampuan untuk memvisualisasikan gambar di dalam otak dan menciptakan atau mengeksplorasi dalam bentuk 2D atau 3D.Lazear di Jasmine (2007: 22) menambahkan kecerdasan spasial sering mengetahui dengan membayangkan dan memiliki peran.

Kinestetik adalah potensi menggunakan seluruh tubuh seseorang atau bagian tubuh, seperti yang digunakan dalam atletik, menari, akting, kerajinan, dan menggunakan alat.Menurut Jasmine (2007: 25) orang-orang yang memiliki kecerdasan kinestetik tinggi lebih nyaman untuk mengkomunikasikan informasi dengan menunjukkan atau modeling.Armstrong (2000: 3) menambahkan bahwa kecerdasan ini melibatkan kemampuan fisik tertentu seperti koordinasi, keseimbangan, keterampilan, kekuatan, kelenturan, kecepatan, kemampuan untuk merespon stimulus (proprioseptif) dan sesuatu berhubungan dengan menghubungi (taktil dan haptic).

Musik adalah potensi berpikir dalam musik; untuk mendengar, mengenali, dan mengingat pola, seperti yang digunakan dalam menyanyi, mengidentifikasi suara, dan dalam mengingat melodi dan ritme.Musik Intelligence (musik cerdas), berdasarkan Carlson (1997: 12), adalah kapasitas untuk berpikir dalam musik, untuk dapat mendengar pola, mengenali mereka, dan mungkin memanipulasi mereka.Jasmine (2007: 22) menambahkan orang-orang yang memiliki kecerdasan musikal yang sangat sensitif dengan suara.Interpersonal adalah potensi untuk bekerja dengan orang lain, seperti yang digunakan dalam memahami orang, memimpin dan mengatur orang 
lain, berkomunikasi, menyelesaikan konflik, dan penjualan. Kecerdasan interpersonal tidak dilahirkan dengan kami tetapi sesuatu yang harus dibangun sebagai kecerdasan lain Lwin, et al (2008: 197) menjelaskan jenis kecerdasan memungkinkan kita untuk membangun hubungan yang baik, pengaruh, dan kepemimpinan dengan masyarakat. Jasmine (2007: 26) menyatakan orang-orang yang memiliki kecerdasan ini seperti dan menikmati bekerja bersama-sama atau dalam kelompok. Kecerdasan interpersonal berdasarkan Armstrong (2000: 4) dapat dikatakan sebagai kemampuan untuk dipersepsikan dan membedakan perasaan dan motivasi yang lain.

\section{Prinsip Multiple Intelligences}

Setiap anak memiliki banyak cara untuk menjadi jenius seperti yang dinyatakan oleh Armstrong (2005: 4) bahwa hal itu dapat dengan kata-kata, angka, gambar, musik, fisik, pengalaman alam, interaksi sosial, pemahaman diri sehingga diperlukan berbagai kegiatan untuk mendukung jenius mereka. Berdasarkan Solmundardottir (2008: 3), teori kecerdasan ganda memiliki satu titik utama yang setiap individu memiliki delapan kecerdasan dan mereka semua bekerja bersama-sama dengan cara yang unik sehingga mereka saling melengkapi.

Selain deskripsi yang asli delapan kecerdasan dan masing-teoretis, Gardner di Businessballs.com menekankan bahwa:

a) Setiap orang memiliki delapan kecerdasan antara ekstrim terendah dan tertinggi

b) Kebanyakan orang dapat mengembangkan setiap kecerdasan ke tingkat yang memadai kompetensi dengan dorongan yang memadai, pengayaan dan instruksi c) Kecerdasan biasanya bekerja sama dalam cara yang kompleks. Tidak ada satu kecerdasan yang menonjol sendiri, melainkan mereka berinteraksi satu sama lain dalam cara yang kompleks tergantung pada orang.

d) Ada banyak cara untuk menjadi cerdas

\section{Reading}

Membaca adalah salah satu dari empat keterampilan dalam bahasa. Membaca adalah suatu kegiatan untuk memahami beberapa informasi dalam bahasa tertulis. Menurut Pang et al, (2003: 6) membaca terdiri dari dua proses yang terkait, pengenalan kata dan pemahaman. Kata pemahaman mengacu pada proses memahami bagaimana simbol-simbol tertulis sesuai dengan bahasa lisan dan pemahaman mengacu pada proses pembuatan rasa kata-kata, kalimat, dan teks terhubung.

Dari penjelasan singkat di atas, dapat dikatakan bahwa membaca adalah keterampilan bahasa untuk membawa informasi dari teks tertulis. Membaca juga merupakan proses komunikasi antara penulis dan pembaca. Penulis memiliki pesan dalamnya/tulisannya untuk dibagikan. Penulis menempatkan pesan dalam kata-kata ketika pesan masuk ke dalam pikiran pembaca.

\section{Motivasi Membaca}

Memotivasi mahasiswa untuk membaca teks selama proses belajar mengajar adalah salah satu pekerjaan guru. Guthrie dan Wigfield dunia model membaca keterlibatan dalam Vacca dan Vacca (2009: 97) panggilan untuk instruksi yang tidak hanya menggarisbawahi pentingnya pertumbuhan mahasiswa dalam pengetahuan konseptual, mereka menggunakan strategi 
pemahaman, dan interaksi sosial di dalam kelas, tetapi juga motivasi mahasiswa.

Motivasi merupakan kondisi yang penting dari pembelajaran. Hal ini mengacu pada upaya untuk melibatkan mahasiswa sehingga mereka akan mendapatkan tujuan pembelajaran. Sardiman (2007: 89) membagi motivasi menjadi 2 jenis, yaitu:

1) motivasi intrinsik

Motivasi intrinsik adalah motivasi yang berasal dari dalam mahasiswa. Tanpa stimulan dari luar mahasiswa, mahasiswa akan belajar sendiri.

2) motivasi ekstrinsik

Motivasi yang berasal dari luar mahasiswa disebut motivasi ekstrinsik. Para mahasiswa harus dirangsang untuk mempelajari materi oleh sesuatu seperti hadiah. Jenis motivasi ini diperlukan untuk membuat kondisi baik belajar. Akar dari kesulitan mahasiswa membaca adalah sikap mental mahasiswa, mereka mungkin kurang suka membaca.

\section{Reading Comprehension}

Fokus pada informasi yang disampaikan oleh teks lebih potensial untuk kepentingan dalam kegiatan membaca. pemahaman Membaca berdasarkan Hoover dan Tuner pada Urquhart dan Weir (1998: 56) adalah untuk mengekstrak makna yang lengkap dari materi yang disampaikan. Dari definisi tersebut, fokus pada pemahaman yang membaca adalah tentang dan mendapatkan informasi dari teks tertulis.

\section{Multiple Intelligences dalam Pengajaran Bahasa}

Hal ini juga diketahui bahwa sekolah tradisional telah menekankan membaca dan menulis dalam pengajaran bahasa. Selain itu, Sekolah Kurikulum Berbasis memungkinkan sekolah untuk mengelola proses belajar mengajar sendiri. Oleh karena itu, mereka perlu strategi untuk membuat sang pengajar menjadi kreatif dalam proses belajar-mengajar. Strategi kecerdasan ganda seperti yang dinyatakan oleh Armstrong (2000: 51) membuka pintu untuk berbagai strategi pengajaran yang dapat dengan mudah diterapkan di kelas bahasa.Ini memberikan guru untuk kesempatan yang lebih luas untuk memperluas strategi pengajaran modern dengan menggunakan berbagai tugas dan kegiatan. Teori ini dapat digunakan dalam berbagai cara dan bekerja dengan baik dalam sistem sekolah secara keseluruhan. Nolan di Solmundardottir (2008: 6) mengatakan setiap kecerdasan adalah calon di setiap pelajar dan itu adalah bagian dari pekerjaan guru untuk menjaga dan membantu mahasiswa untuk mengembangkan kecerdasan mereka sendiri. Gen (2009: 4) menambahkan guru harus menggunakan kerangka kerja dalam mengajar yang mengembangkan kecerdasan mahasiswa sebagaimana tercantum pada artikelnya Teknologi dan Multiple Intelligences.

Berdasarkan EDUC Journal, ada beberapa lagu yang guru akan dilakukan di beberapa kelas kecerdasan mereka, mereka adalah:

1) Membangkitkan intelijen

Sebuah pelajaran dimulai dengan teka-teki atau otak teaser. Guru membagimahasiswa dalam kelompok dan memberikan masing- 
masing rangkaian teka-teki. Para mahasiswa kemudian bekerja sama untuk memecahkan teka-teki.

2) Memperkuat kecerdasan

Berlatih dengan kecerdasan terbangun dan itu akan meningkatkan. Para mahasiswa berlatih menggambarkan objek yang umum dikenal.

3) Ajarkan untuk/dengan kecerdasan

Para mahasiswa menggambarkan objek dalam diskusi kelompok besar.

4) Mentransfer kecerdasan

Membantu mahasiswa merefleksikan pembelajaran mereka pada tahap sebelumnya dan membantu mereka membuat konten pelajaran yang relevan dengan kehidupan mereka di luar kelas

\section{Proses Penelitian}

Banyak model penelitian tindakan dijelaskan oleh para ahli. Sagor di Mills (2000: 18) menggambarkan sebuah berurutan, lima proses langkah yang meliputi perumusan masalah, pengumpulan data, analisis data, pelaporan hasil, dan perencanaan tindakan. Konsep serupa juga dinyatakan oleh Calhoun di Mills (2000: 18) yang merupakan siklus penelitian tindakan yang meliputi memilih area atau masalah kepentingan bersama, pengumpulan data, pengorganisasian data, menganalisis dan menafsirkan data, dan mengambil tindakan.

Umumnya, Arikunto (2008:18) menjelaskan proses penelitian tindakan dalam empat langkah; mereka (1) perencanaan, (2) tindakan, (3) observasi, dan (4) refleksi. Menurut Kemmis dan McTaggart di Burns (2010: 7) penelitian tindakan biasanya melibatkan empat fase papan dalam siklus penelitian. Siklus pertama mungkin menjadi penerus, atau berulang, spiral dari siklus yang berulang sampai peneliti tindakan telah mencapai hasil yang memuaskan dan merasa sudah waktunya untuk berhenti. Mereka dijelaskan sebagai berikut:

1) Planning. In this phase, I identify a problem or issue and develop a plan of action in order to bring about improvements in a specific area of the research context. This is a forward-looking phase which has to be considered: i) what kind of investigation is possible within the realities and constraints the teaching situation; and ii) what potential improvements those are possible.

2) Action. The plan involves some deliberate interventions into the teaching situation that the research puts into action over an agreed period of time. The interventions are critically informed as the research questions about the current situation and plan new and alternative ways of doing things.

3) Observing. This phase involves observing systematically the effects of the action and documenting the context, actions and opinions of those involved. It is a data collection phase where I use "open-eyed" and "open-minded" tools to collect information about what happening.

4) Reflection. At this point, I reflect on, evaluate and describe the effects of the action in order to make sense what has happened and to understand the issue have explored more clearly. I may decide to do further cycles of action research to improve the situation. The following figure is the model of the research adapted from Kemmis and McTaggart in Burns (2010:8). 


\section{METODOLOGI}

\section{Metode Penelitian}

Dalam penelitian ini menggunakan penelitian tindakan untuk meningkatkan motivasi belajar mahasiswa pada reading comprehension dengan menggunakan strategi Multiple Intelligences. Bab ini terdiri dari beberapa bagian, yaitu subjek penelitian, desain penelitian, instrumen pengumpulan data, prosedur pengumpulan data dan prosedur untuk analisis data. Bagian-bagian akan dijelaskan sebagai berikut:

\section{Cycle I}

Setelah melakukan studi pendahuluan, saya menerapkan siklus pertama. Itu dibangun untuk melaksanakan Beberapa strategi Intelligences ke dalam proses belajar mengajar dan mengetahui peningkatan motivation. The siklus pertama mahasiswa terdiri dari empat kegiatan, yaitu:

\section{1) Perencanaan}

Saya membangun sebuah rencana pelajaran tentang teks naratif.Itu dibangun dengan berbagai kegiatan dengan menggunakan beberapa strategi kecerdasan untuk meningkatkan motivasi mahasiswa dalam membaca pemahaman.Selain itu, saya membuat alat peraga untuk mendukung pengajaran dan digunakan rubrik sebagai penilaian otentik dari kinerja mereka di kelas.Saya juga membuat lembar observasi untuk mengumpulkan data.

2) Bertindak

Setelah persiapan itu diselesaikan, saya menerapkan strategi multiple intelligences. Hal pertama yang saya memperkenalkan secara singkat kepada mahasiswa adalah konsep Beberapa strategi Intelligences dalam bahasa Inggris kelas belajar kemudian, diikuti oleh beberapa kegiatan membaca yang mempekerjakan kecerdasan untuk meningkatkan motivasi membaca mereka. Saya membuat aksi menjadi 2 pertemuan, sehingga strategi Multiple Intelligences efektif mempengaruhi mahasiswa dalam belajar mereka.

3) Mengamati

Pada fase ini, saya mengamati perilaku mahasiswa dan melihat efek dari tindakan. Saya mencatat isi proses belajar mengajar, tindakan, dan opini menggunakan checklist pengamatan. Hasil pengamatan digunakan untuk mengenali efek dari beberapa strategi Intelligences untuk meningkatkan motivasi mahasiswa dalam membaca.

4) Mencerminkan

Dalam titik ini, saya merenungkan, dievaluasi dan menggambarkan efek dari tindakan dalam rangka untuk memahami apa yang telah terjadi dan memahami masalah telah dieksplorasi lebih jelas dan untuk mengetahui apakah Beberapa strategi Intelligences memberi perbaikan atau tidak. Saya mengidentifikasi keberhasilan dan kegiatan gagal dan menjelaskan mengapa mereka terjadi. Karena masih ada beberapa kelemahan, jadi saya memutuskan untuk siklus kedua dilaksanakan sebagai revisi yang pertama untuk menunjukkan hasil yang maksimal.Saya melakukan siklus kedua dengan modifikasi aktivitas.Oleh karena itu, saya menggunakan hasil refleksi siklus I sebagai pertimbangan untuk siklus II. 


\section{Cycle II}

Siklus kedua dibangun untuk merevisi kegiatan pada siklus pertama untuk mendapatkan hasil yang maksimal dari efek Beberapa strategi Intelligences dalam meningkatkan motivasi mahasiswa dalam membaca pemahaman. Mirip dengan siklus pertama, yang kedua terdiri empat langkah, yaitu:

1) Perencanaan

Pada siklus kedua, saya direkonstruksi kegiatan dengan pertimbangan refleksi siklus pertama.Itu dibuat sebagai solusi dari kelemahan dan memberikan peningkatan maksimal dalam motivasi mahasiswa dalam membaca.

2) Bertindak

Aku mengambil tindakan dari rencana revisi untuk mendapatkan peningkatan maksimal dalam pengaruh Beberapa strategi Intelligences pada mahasiswa memotivasi dalam membaca pemahaman. Pada fase ini, saya membuat pertemuan 2 dengan tujuan yang sama untuk membuat mahasiswa benar-benar merasa efek strategi Multiple Intelligences dalam pembelajaran mereka.

Pada pertemuan kedua, saya memberikan kuesioner untuk mendapatkan respon mahasiswa tentang kegiatan menggunakan strategi multiple intelligences.

3) Mengamati

Ketika aku sedang mengajar, saya juga mengamati efek dari penerapan multiple intelligences strategi terjadi di kelas dengan menggunakan checklist observasi.Hasil pengamatan kedua digunakan untuk mengenali bagaimana peningkatan motivasi mahasiswa dalam membaca pemahaman setelah diajarkan menggunakan strategi Multiple Intelligences.

4) Mencerminkan

Pada tahap ini, saya kritis tercermin tahap tindakan kedua, dievaluasi dan menggambarkan efek dari tindakan kedua untuk mengetahui apak ah tindakan kedua terus bekerja dengan baik atau tidak. Hasil refleksi menunjukkan peningkatan dari siklus pertama. Berdasarkan hasil tersebut, ada tidak perlu melakukan siklus berikutnya dalam penelitian ini. Secara umum, dapat disimpulkan bahwa motivasi belajar mahasiswa baik.

\section{Instrumen untuk Pengumpulan Data}

Dalam penelitian ini, peneliti menggunakan beberapa strategi Intelligences beberapa kegiatan yang dilakukan pada kecerdasan mahasiswa dan mengamati kegiatan belajar mengajar.

Prosedur pengumpulan data dibagi menjadi 2 bagian, yaitu:

\section{Tahap Persiapan}

Sebelum melakukan penelitian, saya siap hal untuk mendukung penelitian.Pertama-tama, saya merancang siklus I dengan membangun rencana pelajaran sebagai pedoman dalam melakukan penelitian.Aku memilih Beberapa strategi Intelligences sebagai solusi dari masalah yang diidentifikasi dalam studi pendahuluan. Selain itu, peneliti juga membuat lembar observasi untuk memantau kegiatan kelas.

\section{Tahap Action}

Tahap bertindak menerapkan beberapa strategi kecerdasan adalah tindakan apa yang sudah direncanakan. Ini dibagi menjadi 2 siklus, deskripsi adalah sebagai berikut : 
a. Cycle I

Siklus pertama terdiri dari 2 pertemuan di mana setiap pertemuan menerapkan Beberapa strategi Intelligences dalam kegiatan membaca.

b. Cycle II

Siklus kedua terdiri dari 2 pertemuan di mana setiap pertemuan dilaksanakan Multiple Intelligences strategi untuk kegiatan membaca.

\section{HASIL DAN PEMBAHASAN}

\section{Hasil Penelitian Cycle 1}

Ada 2 pertemuan pada siklus pertama. Pertemuan pertama dilakukan pada mahasiswa Fakultas Kesehatan Semester I Universitas Muhammadiyah Palangkaraya. Pertemuan pertama, menjelaskan tentang pengetahuan umum teks naratif, seperti fungsi sosial, struktur generik, dan fitur bahasa teks naratif. Selain itu, memperkenalkan penelitian yang dilaksanakan di kelas dengan memberikan penjelasan singkat tentang strategi yang digunakan dalam proses pembelajaran, apa yang harus mereka lakukan, dan tujuan penelitian. Kemudian, saya mulai mengajar dengan memberikan gambaran permainan dari cerita yang dibacakan oleh mahasiswa kemudian, eksplorasi untuk menangkap perhatian mereka dalam kelompok.

\section{Observasi}

Selama dalam proses belajar membaca, saya mencatat semua kejadian dalam lembar observasi. Ada 15 item yang diamati dalam penelitian, 3 item pemahaman teks dan 12 item dari kebiasaan belajar. Pengamatan dilakukan untuk setiap mahasiswa dalam proses pembelajaran.

\section{Cycle 2}

Ada 2 pertemuan di siklus 2. Pertemuan pertama, saya memberikan strategi yang berbeda dari siklus pertama, yaitu mengelompokkan strategi. Beberapa jenis teks pada dinding harus diklasifikasikan oleh mahasiswa. Para mahasiswa dibagi menjadi 6 kelompok. Mereka berpindahpindah kelas untuk membaca teks pada gilirannya. Para mahasiswa melakukan kegiatan dengan senang hati dan semua mahasiswa yang terlibat dalam kegiatan praktis ini. Mereka diklasifikasikan narasi dari teks atau jenis lainnya. Secara tidak langsung, mahasiswa membaca dan mencoba memahami teks dengan baik untuk dapat menyelesaikan tugas.

\section{Observasi}

Sama seperti siklus pertama, proses belajar membaca pada siklus 2 tercatat lembar observasi yang digunakan. Setiap mahasiswa sudah dilakukan observasi dalam proses belajar.

\section{Refleksi}

Umumnya, hasil dari siklus kedua sangat baik. Para mahasiswa menunjukkan peningkatan pada setiap indikator motivasi mereka dalam membaca dan kebiasaan belajar mereka. Pengajar mampu menerapkan strategi yang melibatkan mahasiswa pada proses pembelajaran. Jadi belajar itu tidak berpusat pada guru lagi. Para mahasiswa menikmati kegiatan menyenangkan sehingga mereka tidak bosan ketika mereka diminta untuk belajar membaca.

Ada 2 indikator pada siklus kedua yang masih dalam tingkat yang sama dengan siklus pertama, tapi ada peningkatan persentase, seperti pada Tabel 3. yaitu mereka menyelesaikan 
Tabel 1. Hasil Observasi dari Sikus I

\begin{tabular}{clccc}
\hline \multirow{2}{*}{ No. } & \multicolumn{1}{c}{ Indicator } & \multicolumn{2}{c}{ Score (\%) } & Criteria \\
\cline { 2 - 4 } & & Meeting 1 & Meeting 2 & (Likert scale) \\
\hline 1. & Readiness on reading & 71 & 77 & Good \\
2. & Concentrate while reading & 71 & 75 & Good \\
3. & Respond to teacher questioning & 67 & 70 & Average \\
4. & Pay attention to teacher explanation & 68 & 73 & Good \\
5. & Participate in group activities & 68 & 73 & Good \\
6. & Interact with other & 70 & 81 & Good \\
7. & Finish the task in time and completely & 82 & 81 & Good \\
8. & Present the tasks result & 82 & 85 & Good \\
9. & Follow the practical activities & 68 & 80 & Good \\
10. & Make use of book/ dictionary & 60 & 70 & Average \\
11. & Obey the class rules & 78 & 83 & Good \\
12. Summarize the information & 65 & 70 & Average \\
\hline
\end{tabular}

Tabel 2. Hasil Observasi dari Siklus II

\begin{tabular}{clccc}
\hline \multirow{2}{*}{ No. Indicator } & \multicolumn{1}{c}{ Score (\%) } & Criteria \\
\cline { 3 - 4 } & & Meeting $\mathbf{1}$ & Meeting 2 & (Likert scale) \\
\hline 1. & Readiness on reading & 85 & 89 & Excellent \\
2. & Concentrate while reading & 90 & 91 & Excellent \\
3. & Respond to teacher questioning & 90 & 90 & Excellent \\
4. & Pay attention to teacher explanation & 95 & 95 & Excellent \\
5. & Participate in group activities & 89 & 89 & Excellent \\
6. & Interact with other & 84 & 87 & Excellent \\
7. & Finish the task in time and completely & 82 & 82 & Good \\
8. & Present the tasks result & 93 & 94 & Excellent \\
9. & Follow the practical activities & 93 & 95 & Excellent \\
10. & Make use of book/ dictionary & 85 & 86 & Excellent \\
11. Obey the class rules & 96 & 96 & Excellent \\
12. Summarize the information & 79 & 80 & Good \\
\hline
\end{tabular}

Tabel 3. Peningkatan Mahasiswa dalam Pemahaman Membaca

\begin{tabular}{|lll}
\hline \multicolumn{1}{c}{ Preliminary Study } & \multicolumn{1}{c}{ Cycle 1 } & \multicolumn{1}{c}{ Cycle 2 } \\
\hline When the teacher gave & When the teacher gave & When the teacher gave \\
questions about the text & CARI 1 to check the & CARI 2 to check the \\
which they have read, & students' comprehension, & students' comprehension, \\
only a few students who & many students got score & most of the students got \\
could answer, the others & 100 point, but still found & score 100 point and no \\
were not able to answer & 3 students who got score 50 & students were under the minimal point \\
\hline
\end{tabular}


tugas dalam waktu tertentu dan meringkas informasi dari teks. Keterbatasan waktu adalah masalah, itu membutuhkan manajemen waktu yang baik yang lain, mahasiswa membaca dan melakukan kegiatan dengan antusias dan tidak merasa di bawah tekanan. Selain itu, saya memberi lebih banyak umpan balik dalam setiap kegiatan, sehingga mahasiswa menjadi termotivasi untuk berpartisipasi. Berdasarkan hasil, tidak ada kebutuhan untuk melakukan siklus berikutnya dalam penelitian ini.

\section{KESIMPULAN DAN SARAN}

\section{Kesimpulan}

1. Masalah yang dihadapi oleh mahasiswa dalam pemahaman membaca (reading comprehension) adalah memotivasi mereka dalam membaca. Oleh karena itu, dengan menggunakan strategi Multiple Intellegences kegiatan pembelajaran menjadi menarik, sehingga mahasiswa termotivasi dalam membaca dan memiliki perilaku positif dalam proses belajar membaca.

2. Strategi Multiple Intellegences dapat digunakan sebagai salah satu strategi alternatif, yang menggabungkan kecerdasan mahasiswa dalam memecahkan pertanyaan pemahaman membaca. Multiple Intelligences instruksional yang digunakan dalam setiap kegiatan; seperti such as puzzle, teks naratif, pemetaan cerita, mengklasifikasikan, dan bermain peran. Jadi setelah memahami teks bacaan, mahasiswa mendapatkan informasi dari teks. Kekuatan dari Multiple Intelligences strategi adalah membuat mahasiswa belajar dengan sendiri, memotivasi mahasiswa belajar, menghindari kebosanan, membantu mahasiswa untuk proses belajar aktif dan kreatif.

\section{Saran}

1. Strategi Multiple Intelligences adalah strategi alternatif untuk beragam bacaan mengajar dan referensi bagi pengajar lainnya.

2. Ada begitu banyak hal dalam strategi Multiple Intelligences untuk dieksplorasi. Strategi ini hanya difokuskan pada memotivasi mahasiswa dalam membaca, dan disarankan ada kesempatan bagi peneliti lain dalam konteks yang berbeda.

\section{DAFTAR PUSTAKA}

Abdulkader, F. A. 2006. The Effectiveness of Multiple Intelligences-Based Program in Improving Certain Reading Skills in $5^{\text {th }}$ Year Primary Learning Disabled Students. Turkey: Electronic Journal of Research in Educational Psychology, 7(3). Pg. 680

Burns, A. 2010. Doing Action Research in English Language Teaching- a Guidefor Practitioners. New York: Routledge-Taylor and Francis Group.

Chatib, M. 2009. Sekolahnya Manusia : Sekolah Berbasis Multiple Intelligences. Bandung: Kaifa.

Chatib, M. 2011. Gurunya Manusia: Menjadikan Semua Anak Istimewa dan Semua Anak Juara. Bandung: Kaifa.

Curtis, K. R. 2008. Conducting Market Research Using Primary Data. Nevada: Department of Resource Economics, University of Nevada. 